\title{
Improvement of Learning Outcomes Using Interactive Media in SDN 1 Sendang
}

\author{
Asmuni \\ SDN 1 Sendang \\ Asmunionce1@gmail.com
}

\section{Article History}

accepted 14/11/2020

approved $21 / 11 / 2020$

published 26/11

\begin{abstract}
This research was carried out with the aim of improving student learning outcomes in online learning with interactive media for grade 4 SD Negeri 1 Sendang students. This type of research is classroom action research (PTK). The subjects were grade 4 students of SD Negeri 1 Sendang, Todanan District, Blora Regency, totaling 15 students. The design of CAR uses interactive media to improve student learning outcomes in Thematic Subject 5 for grade 4 students of SD Negeri 1 Sendang. Data collection techniques using observation and tests. The data analysis used descriptive quantitative and qualitative statistics.

The results showed an increase in student learning outcomes, this can be seen from the results of the evaluation of the pre-action activities and each cycle, namely the pre-action by $33.3 \%$., In the first cycle it was $53.3 \%$, in the second cycle it was $66 \%$, while the third cycle was $87 \%$. Thus it can be concluded that the use of interactive media can improve student learning outcomes in thematic learning.
\end{abstract}

Keywords: Interactive media, thematic, learning outcomes

\begin{abstract}
Abstrak
Penelitian ini dilaksanakan dengan tujuan untuk meningkatkan hasil belajar siswa pada pembelajaran daring dengan media interaktif siswa kelas 4 SD Negeri 1 Sendang. Jenis penelitian ini adalah penelitian tindakan kelas (PTK). Subjeknya adalah siswa kelas 4 SD Negeri 1 Sendang Kecamatan Todanan Kabupaten Blora yang berjumlah 15 siswa. Desain PTK menggunakan media interaktif untuk meningkatkan hasil belajar siswa pada mata pelajaran Tematik Tema 5 bagi siswa kelas 4 SD Negeri 1 Sendang. Teknik pengumpulan data menggunakan observasi dan tes. Analisis data yang digunakan statistik deskriptif kuantitatif dan kualitatif. Hasil penelitian menunjukkan adanya peningkatan hasil belajar siswa, hal ini dapat dilihat dari hasil evaluasi dari kegiatan pra tindakan dan setiap siklus, yaitu pada pra tindakan sebesar $33,3 \%$., pada siklus I sebesar $53,3 \%$, pada siklus II sebesar $66 \%$, sedang siklus III sebesar $87 \%$. Dengan demikian dapat disimpulkan bahwa penggunaan media interaktif dapat meningkatkan hasil belajar siswa pada pembelajaran Tematik.
\end{abstract}

Kata kunci: Media interaktif, tematik, hasil belajar

Social, Humanities, and Education Studies (SHEs): Conference Series https://jurnal.uns.ac.id/shes

p-ISSN 2620-9284 e-ISSN 2620-9292 


\section{PENDAHULUAN}

Pembelajaran tematik yang tercantum dalam Kurikulum 2013 tersebut sudah mengandung konsep dan ide yang dapat mengantisipasi perkembangan ilmu pengetahuan secara global. Tujuan pembelajaran tematik dirancang sedemikian rupa agar siswa mampu mengembangkan pengetahuan dan keterampilan proses. Selain itu, mampu memecahkan masalah dan mampu membuat keputusan terhadap suatu persoalan dalam kehidupan sehari-hari. Pada pemecahkan masalah pembelajaran tema dalam kehidupan sehari-hari diperlukan usaha manusia dalam memahami alam semesta melalui pengamatan yang tepat sasaran, menggunakan prosedur dan dijelaskan dengan penalaran untuk menarik kesimpulan (Susanto, 2013:167). Oleh sebab itu, pembelajaran tematik saling keterkaiatan antara muatan yang satu dengan yang lainnya perlu diajarkan sejak usia sekolah dasar sehingga anak siap untuk memecahkan masalah sehari- hari.

Dari hasil pembelajaran yang penulis lakukan selama penulis mengajar kelas IV mengenai pembelajaran daring menunjukan 50\% lebih siswa mengalami kesulitan dalam mengikuti pembelajaran. Penyebabnya siswa kurang aktif dalam pembelajaran daring. Diduga hal ini terjadi siswa merasa bosan dengan pembelajaran daring yang di laksanakan. Jika keadaan seperti itu berlanjut sangat berpengaruh dengan hasil belajar siswa. Oleh karena itu dalam kesempatan ini penulis berupaya membuat solusi dengan menawarkan pembelajaran daring dengan menerapkan media interaktif untuk meningkatkan hasil belajar siswa.

H.M. Surya (2008:8.6) menyatakan hasil belajar ditandai dengan perubahan tingkah laku secara keseluruhan. Perubahan tingkah laku sebagai hasil belajar meliputi aspek tingkah laku kognitif, konotatif, afektif atau motorik. Belajar yang hanya menghasilkan perubahan satu atau dua aspek tingkah laku saja disebut belajar sebagian dan bukan belajar lengkap.

Media pembelajaran interaktif adalah suatu sistem penyampaian pengajaran yang menyajikan materi video rekaman dengan pengendalian komputer kepada penonton (siswa) yang tidak hanya mendengar dan melihat video dan suara, tetapi juga memberikan respon yang aktif, dan respon itu yang menentukan kecepatan dan sekuensi penyajian Seels \& Glasgow (Arsyad, 1997:36).

Secara garis besar PTK ini mengacu pada penggunaan media interaktif pada pembelajaran daring. Masalah yang dipecahkan bersama akan disimpulkan bersama, peran guru hanya sebagai fasilitator yang mengarahkan siswa untuk mencapai tujuan belajar. Dalam aktivitas siswa selama pembelajaran daring dengan menggunakan media interaktif benar - benar memberdayakan potensi siswa untuk mengaktualisasikan pengetahuan dan ketrampilannya.

\section{METODE}

Penelitian ini berlokasi di SDN 1 Sendang Kecamatan Todanan Kabupaten Blora. Penelitian dilaksanakan pada pertengahan semester gasal tahun pelajaran 2020/2021 sesuai dengan materi Tematik. Subjek penelitian tindakan kelas ini adalah siswa kelas IV SDN 1 Sendang Kecamatan Todanan Kabupaten Blora tahun pelajaran 2020/2021. Sebanyak 15, yang terdiri dari 4 siswa perempuan dan 11 siswa laki-laki.

Penelitian ini adalah penelitian tindakan kelas (Classroom Action Research) dengan menerapkan media interaktif. Penelitian ini dilaksanakan selama tiga siklus secara daring menggunakan aplikasi Zoom Meeting dengan satu pertemuan disetiap siklusnya. Siklus I dilaksanakan pada tanggal 16 November 2020. Siklus II dilaksanakan pada tanggal 23 November 2020. Dan siklus III dilaksanakan pada tanggal 4 Desember 2020. Teknik pengumpulan data yang dilakukan dengan observasi dan tes, baik pre test maupun post test. Observasi meliputi observasi 
keaktifan siswa dalam pembelajaran, sikap peserta didik dan keterampilan. Untuk hasil belajar menggunakan tes melalui Google form.

\section{HASIL DAN PEMBAHASAN}

Hasil penelitian tindakan kelas ini diperoleh dari tindakan pra siklus (pre tes), siklus I, siklus II, dan siklus III. Hasil tes tindakan siklus I dan siklus II Tema 5 pahlawanku sedangkan hasil non tes berupa perubahan perilaku yang diperoleh melalui catatan harian guru, catatan harian siswa dan dokumentasi foto. Kondisi awal hasil belajar dan aktifitas belajar siswa kelas IV pada dari jumlah 15 siswa yang memperoleh nilai tuntas hanya 5 siswa atau 33,3\%. Ketika diadakan tindakan pada siklus I kompetensi siswa tentang Tema 5 Pahlawanku ada peningkatan demikian pula keaktifan siswa mulai tampak meskipun belum signifikan. Adapun hasil dari siklus I adalah sebagai berikut.

Tabel 1. Kompetensi Siswa Siklus I

\begin{tabular}{cccc}
\hline No. & Nilai & $\begin{array}{c}\text { Jumlah } \\
\text { Siswa }\end{array}$ & Prosentase \\
\hline 1 & $\geq 70$ & 7 & $46,7 \%$ \\
2 & $<70$ & 8 & $53,3 \%$ \\
& Jumlah & 15 & 100 \\
\hline
\end{tabular}

Tabel 2. Keaktifan Siswa Siklus I

\begin{tabular}{|c|c|c|c|c|c|}
\hline \multirow[b]{2}{*}{ No } & \multirow[b]{2}{*}{ Jumlah } & \multicolumn{4}{|c|}{ Aspek yang dinilai } \\
\hline & & 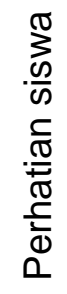 & 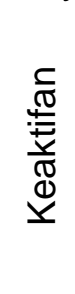 & 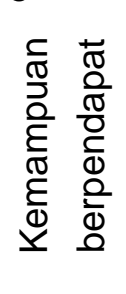 & 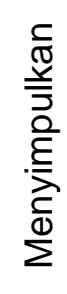 \\
\hline 1 & Jumlah siswa & 8 & 7 & 4 & 2 \\
\hline 2 & Presentase & 53 & 46 & 26 & 13 \\
\hline
\end{tabular}

Dari data tersebut di atas dapat kita lihat hasil pada tindakan siklus I yang berkaitan dengan kompetensi jumlah siswa yang mendapat nilai 70 ke atas ada 8 siswa sekitar 53,3\% sedangkan yang mendapat nilai kurang dari 70 sejumlah 7 siswa $46,7 \%$. Dari data yang diperoleh pada siklus I tentang keaktifan siswa dapat kita lihat pada proses pembelajaran bahwa siswa yang memperhatikan 8 siswa (53\%), siswa yang aktif 7 orang (46\%), mampu mengemukakan pendapat 4 orang (26\%), dan yang dapat memberikan simpulan 2 orang (13\%). Hasil dari siklus I dijadikan acuan dalam pelaksanaan siklus II.

Karena masih terkendala sinyal dan perangkat dalam proses pembelajaran guru belum menggunakan media dan model pembelajaran secara maksimal. Karena dalam proses pembelajaran sering terjadi lost koneksi sehingga kami sering keluar masuk kelas Sehingga siswa belum mampu memusatkan perhatiaanya secara optimal dalam pelaksanaan pembelajaran. 
SHEs: Conference Series 3 (3) (2020) 1400- 1406

Tabel 3.Kompetensi Siswa Siklus II

\begin{tabular}{|c|c|c|c|}
\hline No. & Nilai & $\begin{array}{l}\text { Jumlah } \\
\text { Siswa }\end{array}$ & Prosentase \\
\hline 1 & & 10 & $66 \%$ \\
\hline 2 & $\begin{array}{l}\geq 70 \\
<70\end{array}$ & 5 & $33 \%$ \\
\hline & Jumlah & 15 & $100 \%$ \\
\hline
\end{tabular}

Dari data tabel 3 tentang kompetensi siswa dapat kita lihat perolehan nilai 70 ke atas terdapat 10 orang atau $66 \%$, sedangkan nilai di bawah 70 ada 5 orang atau $33 \%$. Untuk peran serta siswa dalam proses pembelajaran pada siklus II diperoleh hasil sebagai berikut :

Tabel 4. Keaktifan Siswa Siklus II

\begin{tabular}{|c|c|c|c|c|c|}
\hline \multirow[b]{2}{*}{$\begin{array}{c}\text { No } \\
\text {. }\end{array}$} & \multirow[b]{2}{*}{ Jumlah } & \multicolumn{4}{|c|}{ Aspek yang dinilai } \\
\hline & & 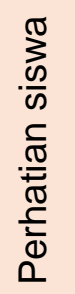 & 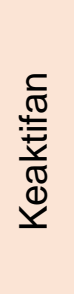 & 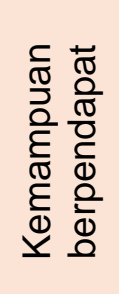 &  \\
\hline 1 & Jumlah siswa & 12 & 10 & 8 & 6 \\
\hline 2 & Presentase & 80 & 66 & 53 & 40 \\
\hline
\end{tabular}

Dari data hasil peran serta peserta siswa dalam proses pembelajaran pada siklus II dapat dilihat untuk perhatian siswa 12 orang atau $80 \%$ penuh perhatian terhadap proses pembelajaran, keaktifan 10 orang atau $66 \%$, kemampuan menyatakan pendapat 8 orang atau $53 \%$, serta menyimpulkan 6 orang atau $40 \%$. Hasil dari siklus II dijadikan acuan dalam pelaksanaan siklus III.

Tabel 5. Kompetensi Siswa Siklus III

\begin{tabular}{|c|c|c|c|}
\hline No. & Nilai & $\begin{array}{l}\text { Jumlah } \\
\text { Siswa }\end{array}$ & Prosentase \\
\hline 1 & & 13 & $87 \%$ \\
\hline \multirow[t]{2}{*}{2} & $\begin{array}{l}\geq 70 \\
<70\end{array}$ & 2 & $13 \%$ \\
\hline & Jumlah & 15 & $100 \%$ \\
\hline
\end{tabular}

Dari data tabel 5 tentang kompetensi siswa dapat kita lihat perolehan nilai 70 ke atas terdapat 13 orang atau $87 \%$, sedangkan nilai di bawah 70 ada 2 orang atau $13 \%$. Untuk peran serta siswa dalam proses pembelajaran pada siklus III diperoleh hasil sebagai berikut : 
Tabel 6. Keaktifan Siswa Siklus III

\begin{tabular}{|c|c|c|c|c|c|}
\hline \multirow[b]{2}{*}{ No } & \multirow[b]{2}{*}{ Jumlah } & \multicolumn{4}{|c|}{ Aspek yang dinilai } \\
\hline & & 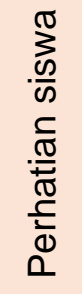 &  & 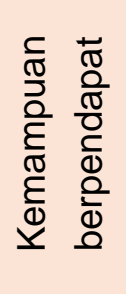 & 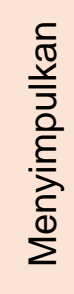 \\
\hline 1 & Jumlah siswa & 13 & 11 & 10 & 9 \\
\hline 2 & Presentase & 87 & 73 & 66 & 60 \\
\hline
\end{tabular}

Dari data hasil peran serta peserta siswa dalam proses pembelajaran pada siklus III dapat dilihat untuk perhatian siswa 13 orang atau $87 \%$ penuh perhatian terhadap proses pembelajaran, keaktifan 11 orang atau $73 \%$, kemampuan menyatakan pendapat 10 orang atau $66 \%$, serta menyimpulkan 9 orang atau $60 \%$.

Berdasarkan hasil observasi dan tindakan pada Siklus I, Siklus II dan Siklus III menunjukkan bahwa pembelajaran dengan media pembelajaran multimedia interaktif yang berlangsung pada siklus III berdampak positif terutama pada peningkatan hasil belajar, keaktifan siswa menjadi lebih baik, komunikasi interaktif antara siswa dan guru terealisir, siswa merasa senang dengan pemberian tugas dari guru. Meskipun secara keseluruhan tindakan belum sempurna betul namun paling tidak siklus III dapat menjawab hipotesa di atas, hal ini dapat dilihat dari perbandingan hasil ketuntasan belajar antara Siklus I, Siklus II dan Siklus III.

Pada siklus I pembelajaran Tema 5 dengan menggunakan media pembelajaran multimedia interaktif yang diterapkan guru sudah cukup baik, dimana hasil pembelajaran dari pembelajaran mencapai $47 \%$ siswa telah mencapai batas tuntas secara individual namun secara klasikal batas ketuntasan belum dapat tercapai, sedangkan pada siklus II hasil dari pembelajaran mencapai $66 \%$ siswa mencapai batas tuntas secara individual; terdapat kenaikan dalam peningkatan hasil sebesar $19 \%$.

Sedangkan pada siklus III hasil dari pembelajaran mencapai $87 \%$ siswa mencapai batas tuntas secara individual; terdapat kenaikan dalam peningkatan hasil dari siklus II sebesar 21\%.Peningkatan hasil belajar siswa pada siklus I,Siklus II dan siklus III dilihat dalam bentuk grafik berikut:

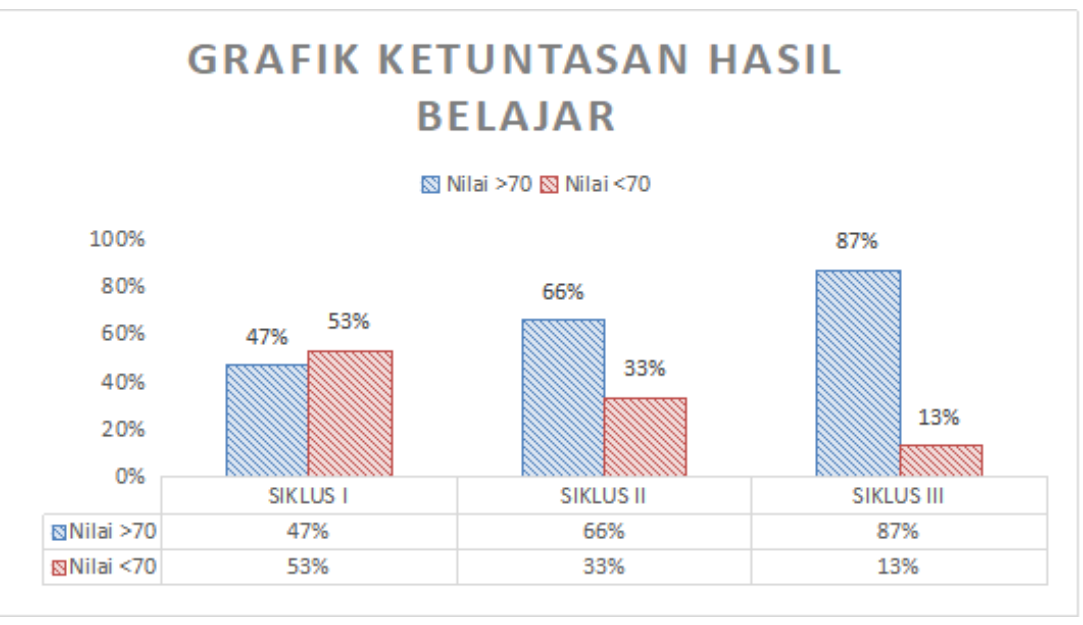




\section{Grafik 1. Perbandingan Ketuntasan Hasil Belajar Siklus I, Siklus II dan Siklus III Prosentase Perbandingan Aktifitas Siswa pada Siklus I, Siklus II dan Siklus III}

\begin{tabular}{ccccc}
\hline No. & Aspek Pengamatan & Siklus I & Siklus II & Siklus III \\
\hline 1 & Perhatian siswa & $53 \%$ & $80 \%$ & $87 \%$ \\
2 & $\begin{array}{c}\text { Keaktifan siswa } \\
\text { Kemampuan }\end{array}$ & $46 \%$ & $66 \%$ & $73 \%$ \\
3 & $\begin{array}{c}\text { berpendapat } \\
\text { benarik }\end{array}$ & $26 \%$ & $53 \%$ & $66 \%$ \\
4 & $\begin{array}{c}\text { Menimpulan } \\
\text { kesimp }\end{array}$ & $13 \%$ & $40 \%$ & $60 \%$ \\
\hline
\end{tabular}

Pada perbandingan aktifitas siswa tampak terdapat adanya peningkatan peran serta siswa dalam mengikuti proses pembelajaran, untuk lebih jelasnya dapat dilihat pada grafik 2.

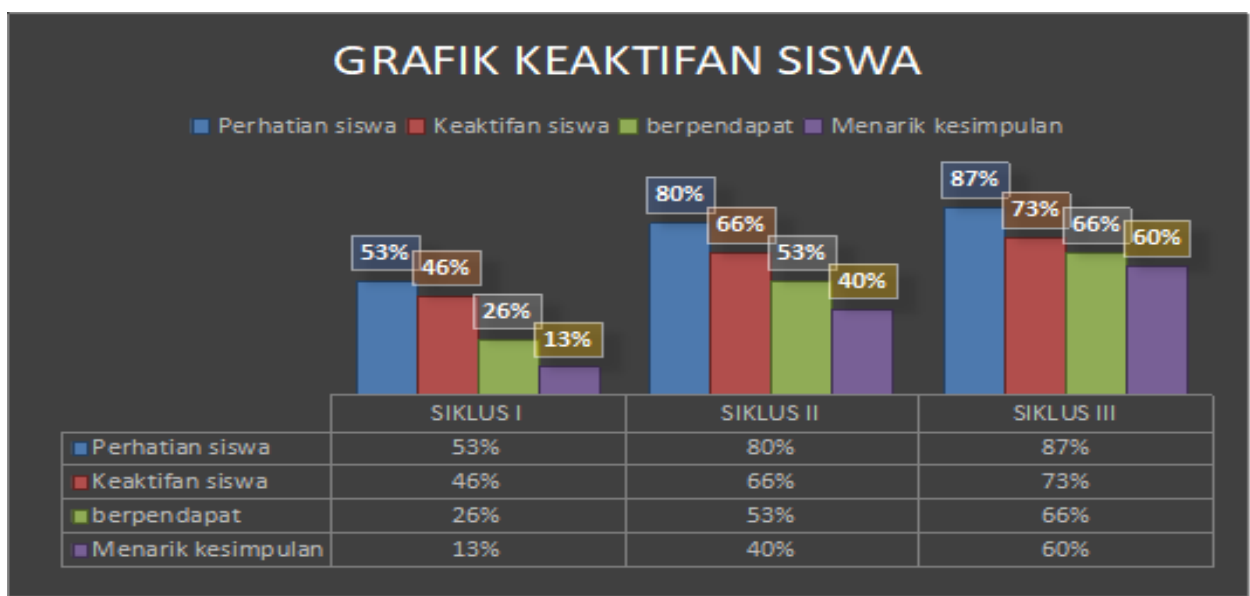

Grafik 2. Perbandingan Keaktifan Siswa pada Siklus I, Siklus II dan Siklus III

Dari hasil pembahasan yang berdasarkan data-data tersebut di atas dapat ditarik kesimpulan bahwa adanya peningkatan kompetensi siswa dan perubahan sikap perilaku siswa dalam pembelajaran Tema 5 Pahlawanku dengan menggunakan media pembelajaran multimedia interaktif, baik dari hasil maupun keaktifan siswa mengalami peningkatan.

\section{SIMPULAN}

Berdasarkan hasil observasi dan tes penguasaan kompetensi dasar pada tiap siklus yang telah dikemukakan pada bab terdahulu, maka dapat ditarik simpulan bahwa dengan Tema 5 dengan menggunakan media pembelajaran multimedia interaktif dapat (1) meningkatkan hasil belajar atau prestasi belajar siswa pada materi Tema 5 Pahlawanku dengan media pembelajaran multimedia interaktif untuk kelas IV di SD Negeri 1 Sendang Kecamatan Todanan Kabupaten Blora Tahun Pelajaran 2020/2021. Terbukti adanya peningkatan ketuntasan hasil belajar dari siklus I, siklus II ke siklus III, (2) meningkatkan aktifitas belajar siswa, pada siklus I, siklus II ke siklus III keaktifan siswa, menyampaikan pendapat dan menyimpulkan terdapat peningkatan . Berdasarkan kesimpulan di atas dapat diberikan saran (1) kepada guru-guru dapat 
melakukan kegiatan penelitian tindakan kelas untuk dapat memecahkan masalahmasalah yang dihadapi di kelas untuk dapat meningkatkan prestasi belajar siswa, (2) melakukan inovasi dalam pembelajaran untuk dapat meningkatkan keaktifan siswa di sekolah, (3) kepada pengelola sekolah, hasil penelitian ini hendaknya dapat digunakan sebagai dasar penentuan kebijakan yang berkaitan dengan pengembangan profesi guru dan peningkatan kualitas pembelajaran.

\section{DAFTAR PUSTAKA}

Arifin, Zainal. 2011. Penelitian Pendidikan : Metode dan Paradigma Baru. Bandung: PT. Remaja Rosdakarya

Arikunto, Suharsimi. 2006. Penelitian Tindakan Kelas. Jakarta : PT. Bumi aksara Asrori, Mohammad. 2007. Penelitian Tindakan Kelas. Bandung : CV. Wacana prima Basrowi. 2008. Prosedur Penelitian Tindakan Kelas. Bogor : Ghalia Indonesia Dalyono. 2009. Psikologi Pendidikan. Jakarta: Rineka Cipta. https://www.dewaweb.com/blog/zoom-meeting/ https://akhmadsudrajat.wordpress.com/2008/03/21/penelitian-tindakan-kelas-part-ii/ http://edriati.blogspot.com/2016/03/model-model-penelitian-tindakankelas_23.html Iskandar. 2009. Penelitian Tindakan Kelas. Ciputat : Gaung persada press Nana Sudjana, Penelitian Hasil Proses Pembelajaran (Bandung : Remaja Rosdakarya, 1989 ), hlm.2

Sugihartono, dkk. 2007. Psikologi Pendidikan. Yogyakarta: UNY Press.

Syamsul Bahri Djamarah, Prestasi Belajar dan Kompetesi Guru, ( Jakarta : Rineka Cipta, 1994)

Wasty Soemanto, Psikologi Pendidikan, (Jakarta : Rineka Cipta, 1990), hlm. 107-114. 